\title{
Trace Metals Distribution in Fish Tissues, Bottom Sediments and Water from Okumeshi River in Delta State, Nigeria \\ ${ }^{1}$ Ekeanyanwu ${ }^{*}$ C.R. ${ }^{1}$ Ogbuinyi C.A ${ }^{1}$ and ${ }^{2}$ Etienajirhevwe $0 . F$
}

\begin{abstract}
Water samples, bottom sediments, Tilapia, and Cat Fish from Okumeshi River in Delta state of Nigeria were analysed quantitatively for the presence of lead, nickel, chromium, manganese and cadmium using Atomic Absorption Spectrophotometer. The fishes contained higher concentration of manganese with a value of $7.77 \mathrm{mg} / \mathrm{kg}$ against $2.76 \mathrm{mg} / \mathrm{kg}$ in sediment and $0.13 \mathrm{mg} / \mathrm{l}$ in water. Studies on the different parts of the fish revealed higher concentrations of $1.97 \mathrm{mg} / \mathrm{kg}$ manganese in the muscle of tilapia fish while the lowest concentration of $0.13 \mathrm{mg} / \mathrm{kg}$ was detected on the gill of catfish. The highest concentration of $0.62 \mathrm{mg} / \mathrm{kg}$ cadmium was detected on the muscle of tilapia while the lowest concentration with a value of $0.04 \mathrm{mg} / \mathrm{kg}$ was recorded in tilapia bone. In most of the fish samples, cadmium concentration was found to be above the maximum tolerable values provided by international institutions.
\end{abstract}

Keywords: Trace metals, Fish Tissues, Water, Bottom sediments, Okumeshi River

\section{Introduction}

The pollution of the aquatic has become a world wide problem in recent times because they are indestructible and most of them have toxic effects on organisms (Macfarlane and Burchett, 2000). Among environmental pollutants, metals are of particular concern, due to their potential toxic effect and ability to bioaccumulate in aquatic ecosystems (Censi et al., 2006). The presence of heavy metals in aquatic ecosystems is the result of two main sources of contamination; natural processes or natural occurring deposits and anthropogenic activities. The main sources of heavy metal pollution to life forms are invariably the result of anthropogenic activities (Kennish, 1992; Francis, 1994). In the fresh water environment, toxic metals are potentially accumulated in sediments and marine organisms and subsequently transferred to man through the food chain. Heavy metal concentrations in aquatic ecosystems are usually monitored by measuring their concentrations in water, sediments and biota (Camuso et al., 1995). These heavy metals generally exist in low levels in water and attain considerable concentration in sediments and biota (Naminga and Wilhm, 1976). Heavy metals including both essential and non essential elements have a particular significance in ecotoxicology, since they are highly persistent and all have the potential to be toxic to living organisms (Storelli et al., 2005).
Studies on heavy metals in rivers, lakes, fish and sediments (Ozmen et al., 2004; Begum et al., 2005; Fernandes et al., 2008; Ozturk et al., 2008; Pote et al., 2008 and Pra veena et al., 2008) have been a major environmental focus especially during the last decade. Sediments have been reported to form the major repository of heavy metal in aquatic system while both allochthonous and autochthonous influences could make a concentration of heavy metals in the water high enough to be of ecological significance (Oyewo and Don-Pedro, 2003). Bioaccumulation and magnification is capable of leading to toxic level of these metals in fish, even when the exposure is low. The presence of metal pollutant in fresh water is known to disturb the delicate balance of the aquatic systems. Fishes are notorious for their ability to concentrate heavy metals in their muscles and since they play important role in human nutrition, they need to be carefully screened to ensure that unnecessary high level of some toxic trace metals are not being transferred to man through fish consumption (Adeniyi and Yusuf, 2007).

The main objective of this study was to determine the distribution of heavy metal in the fish part, water and bottom sediments of Okumeshi River located in the Ukwuani Local Government Area of Delta State, Nigeria; thereby establishing a baseline data on the current pollution status of the River. The results obtained from this study would also

1Biochemistry Unit, Department of Chemical Sciences, Novena University, Ogume, Nigeria

${ }^{1}$ ekeanyanwuraphael@yahoo.com

2 Science Laboratory Technology Departments, Delta State Polytechnic, Otefe, Nigeria 
provide information for background levels of metals in the water, sediments and fish species of the River, environmental quality of organisms in the river and health implication of the people inhabiting the areas around the river.

\section{Materials and Methods Study Area}

Amai is a semi urban area located in the Ukwuani local government area of Delta State, Nigeria. It is also the host community of one of the campuses of Novena University. Approximately 50,000 people live in Amai and its surroundings, where agriculture is the main income. The Okumeshi River is one of the important rivers in these areas. The Okumeshi River is generally used for irrigation of the agricultural areas in and around Amai. The river also serves as source of drinking water and fish for the inhabitants of this area.

\section{Sample Collection and Preparation}

Two fish samples Cat fish (Chrysichthys nigrodidatatus) and Tilapia (Tilapia nilotica) were collected from Okumeshi River. Fish specimens weighing 269.7g were collected and dissected for gills, liver, muscles and bones. Bottom sediments and water was also collected from the River. All samples were prepared following standard protocols (Welz and Sperling, 1999). About 10 - $15 \mathrm{~g}$ of the native organs were taken into crucibles and dried inside a muffle furnace at $1500^{\circ} \mathrm{C}$ for 3 hours. These were cooled to room temperature and the dried weight taken. These were then transferred to the cooled muffle furnace and slowly the temperature was raised to a range $500 \pm 50^{\circ} \mathrm{C}$ for 11 hours. The samples were removed and cooled inside the desiccators to room temperature. A volume, $2.0 \mathrm{ml}$ of concentrated $\mathrm{HNO}_{3}$ was added into the crucible and swirled, then acidified as was gently warmed on a hot plate till evaporation of $\mathrm{NO}_{2}$ ceased and then heating continued to evaporate the acid completely. The mass thus formed was transferred into the cool furnace once again. The furnace was gradually heated to a range of $450-500^{\circ} \mathrm{C}$ for 2 hours, and then the mass was cooled to room temperature. The process was repeated once again until white coloured ash was obtained. $1.0 \mathrm{ml}$ of $1.0 \mathrm{~N} \mathrm{HCl}$ was added and the mixture was gently warmed until a clear solution was obtained. These were then cooled and transferred into $25 \mathrm{ml}$ volumetric flasks. Distilled water was added up to the mark and stored inside an incubator at $20^{\circ} \mathrm{C}$.

\section{Water Samples}

About $200 \mathrm{ml}$ of water sample collected from the River was filtered through Whatman $0.45 \mu \mathrm{m}$ glass fibre filter and transferred to acid cleaned $250 \mathrm{ml}$ polypropylene bottles and then acidified with concentrated Nitric acid to $\mathrm{pH}$ not exceeding 2.0.

\section{Bottom Sediment Samples}

Bottom sediment sample collected from the River was dried $\left(80 \pm 10^{\circ} \mathrm{C}\right.$ for 10 hours in a hot air oven) homogenised and sieved for extraction of lead, nickel, chromium, manganese and cadmium from dry ashes. About $1.0 \pm 0.05 \mathrm{~g}$ dried and grounded sediment samples were placed inside a crucible and ignited in a muffle furnace at $500^{\circ} \mathrm{C}$ for 3 hours. The ignited mass was cooled inside desiccators and transferred into a $100 \mathrm{ml}$ borosil beaker and $10 \mathrm{ml}$ concentrated $\mathrm{HCl}$ was added and the suspension swirled. The suspension was kept inside a thermostat controlled water bath in a temperature range of $70-80^{\circ} \mathrm{C}$ for 1 hour. The supernatant was decanted and kept inside a $100 \mathrm{ml}$ volumetric flask. This contains mostly alkaline earth metals. To the residue in the beaker, $10 \mathrm{ml}$ each of $\mathrm{HCl}$ (concentrated) and $\mathrm{HClO}_{4}$ (concentrated, $70 \%$ pure) and few porous beads were added, and was evaporated to dryness over a hot plate. The process was repeated when necessary. The dried residue was dissolved completely by using minimum amount of concentrated $\mathrm{HCl}$. This solution was then transferred to the same volumetric flask where previous extract containing alkaline earth metal extract was stored. The flask were then made up to the mark by distilled water and stored inside a refrigerator. These extracts were analysed for trace metals.

Analysis of Samples: Atomic absorption Spectrophotometry (Buck Scientific Model210) using element specific hollow cathode lamps in default condition by flame absorption mode was used to approximate the metal concentration within samples.

Statistical Analysis: Data were presented as mean of duplicate determinations. 


\section{Results}

Table 1 showed the total extractable metals from Okumeshi River water sediments and other sediment quality guidelines. The heavy metal concentrations in sediment samples decreased in the sequence $\mathrm{Mn}>\mathrm{Cd}>\mathrm{Ni}>\mathrm{Cr}>\mathrm{Pb}$; Table 2 shows the water quality constituent of Okumeshi river and reference freshwater values. Trace metals concentration in the river were decreased in the sequence of $\mathrm{Ni}>\mathrm{Mn}>\mathrm{Cr}>\mathrm{Cd}>\mathrm{Pb}$, and Table 3 showed the trace metals concentration in fish tissues from Okumeshi River samples. The result obtained for tilapia showed that the trace metals concentration were decreased in the sequence $\mathrm{Cd}>\mathrm{Mn}>\mathrm{Ni}>\mathrm{Cr}>\mathrm{Pb}$ in gills, $\mathrm{Mn}>\mathrm{Cd}>\mathrm{Cr}>\mathrm{Ni}>\mathrm{Pb}$ in liver, $\mathrm{Mn}>\mathrm{Cd}>\mathrm{Ni}>\mathrm{Cr}>\mathrm{Pb}$ in muscle and $\mathrm{Mn}>\mathrm{Ni}>\mathrm{Cr}$ and $\mathrm{Cd}>\mathrm{Pb}$ in bones. The result obtained for catfish showed that the trace metals concentration decreased in the sequence $\mathrm{Cd}>\mathrm{Mn}>\mathrm{Ni}>\mathrm{Cr}>\mathrm{Pb}$ in gills, $\mathrm{Mn}>\mathrm{Cd}>\mathrm{Cr}>\mathrm{Ni}>\mathrm{Pb}$ in liver, $\mathrm{Mn}>\mathrm{Cd}>\mathrm{Ni}>\mathrm{Cr}>\mathrm{Pb}$ in muscle and $\mathrm{Mn}>\mathrm{Cd}>\mathrm{Ni}>\mathrm{Cr}>\mathrm{Pb}$ in bones.

Table 1. The trace metal concentration in the Okumeshi River sediment and comparison with sediment quality guidelines (mg/kg dry weight).

\begin{tabular}{|l|l|l|l|l|l|l|}
\hline Locality & Cd & Cr & Mn & Ni & Pb & References \\
\hline $\begin{array}{l}\text { LEL } \\
\text { (Lowest Element Level) }\end{array}$ & 0.60 & 26.0 & - & 16.0 & 31.0 & NOAA, 2009 \\
\hline $\begin{array}{l}\text { TEL } \\
\text { (Threshold Element Level) }\end{array}$ & 0.99 & 43.4 & - & 22.7 & 35.8 & NOAA, 2009 \\
\hline $\begin{array}{l}\text { PEC } \\
\text { (Probable Effect Concentration) }\end{array}$ & 4.90 & 111.0 & - & 48.6 & 128.0 & NOAA, 2009 \\
\hline $\begin{array}{l}\text { SEC } \\
\text { (Severe Effect Level) }\end{array}$ & 10.0 & 110.0 & - & 75.0 & 250.0 & NOAA, 2009 \\
\hline Okumeshi River & 1.32 & 0.87 & 2.76 & 1.21 & 0.45 & This Study \\
\hline
\end{tabular}

Source Lab Analysis 2010

Table 2. The trace metal concentration in Okumeshi River Water and comparison with water quality guidelines (mg/L).

\begin{tabular}{|l|l|l|l|l|l|l|}
\hline Guidelines & Cd & Cr & Mn & Ni & Pb & References \\
\hline SON & 0.005 & 0.05 & 0.2 & 0.02 & 0.01 & SON, 2007 \\
\hline WPCL & 0.003 & 0.02 & - & 0.02 & 0.01 & WPCL, 2004 \\
\hline CIW & 0.01 & 0.1 & - & 0.2 & 5.0 & Anonymous, 1997 \\
\hline WHO & 0.01 & 0.05 & 0.5 & 0.02 & 0.05 & WHO, 2003 \\
\hline EPA & 0.01 & 0.05 & 0.02 & - & 0.05 & EPA, 2002 \\
\hline EC & 5.0 & 50.0 & 0.05 & 20.0 & 10.0 & EC, 1998 \\
\hline Okumeshi River & 0.03 & 0.09 & 0.13 & 0.27 & 0.01 & This study \\
\hline
\end{tabular}

Source Lab Analysis 2010

Table 3. Trace metals Concentration (mg/kg dry weight) in fish tissues from Okumeshi River samples.

\begin{tabular}{|c|c|c|c|c|c|c|}
\hline \multicolumn{2}{|c|}{ Samples } & \multicolumn{5}{|c|}{ Elements } \\
\hline & & $\mathbf{P b}$ & $\mathrm{Ni}$ & $\mathrm{Cr}$ & Mn & Cd \\
\hline \multirow{4}{*}{ 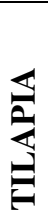 } & Gill & $<0.01$ & 0.11 & 0.06 & 0.17 & 0.21 \\
\hline & Liver & 0.01 & 0.14 & 0.17 & 0.49 & 0.31 \\
\hline & Muscle & $<0.01$ & 0.17 & 0.06 & 1.97 & 0.62 \\
\hline & Bone & $<0.01$ & 0.07 & 0.04 & 1.48 & 0.04 \\
\hline \multirow{4}{*}{ 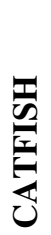 } & Gill & $<0.01$ & 0.05 & 0.04 & 0.13 & 0.14 \\
\hline & Liver & 0.01 & 0.09 & 0.14 & 0.43 & 0.28 \\
\hline & Muscle & $<0.01$ & 0.13 & 0.04 & 1.89 & 0.45 \\
\hline & Bone & $<0.01$ & 0.06 & 0.05 & 1.21 & 0.09 \\
\hline
\end{tabular}

Source Lab Analysis 2010 


\section{Discussion}

The higher elemental concentration bottom sediments of Okumeshi River was in agreement with the concept that bottom sediment contains higher concentrations of metals than that of overlying water (Depinto and Martin, 1980). In the bottom sediments, manganese was found to be of higher concentration with value $2.76 \mathrm{mg} / \mathrm{kg}$, followed by cadmium with value $1.32 \mathrm{mg} / \mathrm{kg}$ and the least was lead with values $0.45 \mathrm{mg} / \mathrm{kg}$. The metal concentrations obtained from the sediment samples were compared with sediment quality guidelines which showed that these concentrations did not exceed the probable effect concentration (PEC) levels (Table 1).

The lead, nickel, chromium, manganese and cadmium concentration in the river water was compared with national and international standards. The result obtained showed that, with the exception of manganese and lead, the trace metal concentrations in water exceeded the WHO (World Health Organisation, 2003), EPA (Environmental Protection Agency, 2002), WPCL (Water Pollution Control Legislation, 2004), CIW (Anonymous, Criterions for irrigation water, 1992) and Standards Organisation of Nigeria (SON, 2007) guidelines (Table 2).

Concentrations of trace metals in fish tissues were always higher than that of water (Chale, 2002). Entry of metals occurs either through gill membrane or through ingestion. Table 3 showed the difference in concentration of trace metals in fish organs as indicated by our study was reported by Mathis and Cummings, 1973; Kalay and Canli, 2000; Bury et al., 2003 and Chatterjee et al., 2006. Accumulation of bioactive metals like lead, nickel, chromium, manganese and cadmium was actively controlled by fish through different metabolic processes and the level of accumulations usually dependent on ambient concentrations. On the other hand, environmental concentrations affect the accumulation of non-essential toxic elements like lead (Pattee and Pain, 2003).

Some bioactive metals play important roles in fish metabolism thus affecting the physiology and pathology of fish. Metals like manganese function as a cofactor in several enzyme systems (Bury et al., 2003). However, when in excessively high concentration, these bioactive metals may pose serious threats to normal metabolic processes.

In fish, gills are considered to be the dominant site for contaminant uptake because of their anatomical and/or physiological properties that maximise absorption efficiency from water (Hayton and Baron, 1990). However, it was evident from our study that, in general muscle and liver were the sites of maximum accumulation for the elements while gill was the overall site of least metal accumulation in both species. Cadmium level in liver and muscle of Tilapia and Catfish were above the tolerable values of trace metals in fish(Table 4). Although, the levels of other trace metals were found to be within permissible limits, bioaccumulation and magnification is capable of leading to toxic level of these metals in fish, even when the exposure is low. There is need for constant monitoring of the trace metals concentration in Okumeshi River since the river serves as source of drinking water, irrigation and fish for the local inhabitants in our study area.

Table 4. The tolerable values of some trace metals ( $\mathrm{mg} / \mathrm{kg}$ dry weight)

\begin{tabular}{|l|l|l|l|l|l|l|}
\hline Source & Cd & Cr & Mn & Ni & Pb & References \\
\hline UNEP & 0.30 & - & - & - & 0.30 & UNEP, 1985 \\
\hline IAEA-407 & 0.18 & 0.73 & 11.0 & 0.60 & 0.12 & Wyse et al., 2005 \\
\hline FEPA & 0.05 & $<0.1$ & 5.0 & - & 0.20 & FEPA, 1991 \\
\hline $\begin{array}{l}\text { Directive } \\
\text { 2005/78/EC }\end{array}$ & 0.05 & - & - & - & 0.20 & EC, 2005 \\
\hline
\end{tabular}




\section{References}

Adeniyi, A.A and Yusuf, K.A. (2007), Determination of heavy metals in fish tissues, water and bottom sediments from Epe and Badagry Lagoons, Lagos, Nigeria. Environmental Monitoring and Assessment, 37, $451-458$.

Anonymous, (1997), Gediz Havzasi Calismalan T.C. Izmir Cevre II Mudurlugu, Turkiye (in Turish).

Begum, A., Amin, M.N., Kaneco, S. and Ohta, K. (2005), Selected elemental composition of fish, Tilapia nilotica, Cirrhina mrigala and Clarius batrachus from the fresh water Dhanmondi Lake in Bangladesh. Food Chemistry, 93, 439 - 443.

Bury, N.R., Walker, P.A and Glover, C.N (2003). Nutritive metal uptake in teleost fish. Journal of Experimental Biology, 206: 11 - 23. Camusso, M., Vigano, L and Baistrini, R. (1995). Bioaccumulation of trace metals in rainbow trout. Ecotoxicology and Environmental Safety, 31: 133 - 141.

Censi, P., Spoto, S.E. Saiano, F., Sprovieri, M., Mazzola, S., Nardone, G., Di Geronimo, S.I., Punturo, R. and Ottonello, D. (2006). Heavy metals in coastal water system. A case study from the north western Gulf of Thailand. Chemosphere, 64: 1167 - 1176.

Chale, F.M. (2002). Trace metal concentration in water,sediments and fish tissues from lake Tanganyika. Science of Total Environment, 299: $155-161$.

Chatterjee, S., Chattopadhyay, B. and Muckhopadhyay, S.K. (2006). Trace metal distribution in tissues of Cichlids (Oreochromis niloticus and O. mossambicus) collected from waste water fed fish ponds in East Calcutta wetlands, A Ramsar site. Acta Ichthyologica et Piscatoria, 36(2): 119 - 125.

Depinto, J.V and Martin, S.C. (1980). Aquatic sediments. Journal of the Water Pollution Control Federation, 52: 1656 - 1670.

EC (European Commision), (2005). Commission Regulation (EC) No. 78/2005 of 19 January 2005 amending regulation (EC) No. 466/2001 as regards heavy metals, L16/43-45.

EC (European Commision), (1998). Council directive 98/83/. EC of November 1998 on the quality of water intended for human consumption. L.330/32, 5.12.98.
EPA (Environmental Protection Agency), (2002). Risk Assessment: Technical background information. RBG table. Available online from http://www.epa.gov./reg3hwmd/risk (online update: 23.03.2009).

FEPA (Federal Environment Protection Agency), (1991). Guidelines to standard for Environment Pollution Control in Nigeria, Lagos, Nigeria.

Fernandes, C., Fontainhas-Fernandes, A., Cabral, D. and Salgado, M.A. (2008). Heavy metals in water, sediment and tissues of Liza saliens from Esmoriz-paramos Lagoon, Portugal. Environmental monitoring and Assessment, 136: 267 - 275.

Francis, B.M, (1994). Toxic substances in the Environment, John Wiley and Sons, Inc, New York, pp.363.

Hayton, W.L and Baron, M.G. (1990). Rate limiting barriers to Xenobiotic uptake by the gill. Environmental Toxicology and Chemistry, 9: $151-157$.

Kalay, M and Canli, M. (2000). Ellimination of essential $(\mathrm{Cu}, \mathrm{Zn})$ and non-essential $(\mathrm{Cd}$, $\mathrm{Pb}$ ) metals from tissues of a fresh water fish, Tillapia zilli. Turkish Journal of Zoology, 24: $429-436$.

Kennish, M.J. (1992). Ecology of Estuaries: Anthropogenic effects. CRC Press Boca Raton Ann Arbor, London, pp. 494.

Macfarlane, G.B and Burchett, M.D. ( 2000). Cellular distribution of $\mathrm{Cu}, \mathrm{Pb}$ and $\mathrm{Zn}$ in the Grey Mangroove Avicemmia marina (Forsk). Vierh Aquatic Botanic, 68: 45 - 49.

Mathis, B.J and Cumming, T.F (1973). Selected metals in sediments, water and biota in the Illinois River. Journal of the Water Pollution Control Federation, 45: 1573 - 1583 Namminga, H.N and Wilhm, J. (1976). Effect of high discharge and an oil refinery clean up operation on heavy metals in water and sediments in skeleton creek. Proceedings of the Oklahoma Academy of Science, 56: 133 - 138. NOAA (National Oceanic and atmospheric Administration), (2009). SQUIRT, Screening quick reference tables for in sediment, http://resposerestoration.noaa.gov/bookshelf/122 NEW-SQUIRTs.pdf (online update: 23.03.2009) 
Oyewo, E.O and Don-Pedro, K.N. (2003). Lethal and Sub lethal effects of copper to the African Catfish (Clarias garienpnus). West Africa Journal of Applied Ecology, 4: 115 123.

Ozmen, H., Kulahci, F., Cukurovali, A and Dogru, M (2004). Concentrations of heavy metals and radioactivity in surface water and sediment of Hazar Lake (Elazig, Turkey). Chemosphere, 55: $401-408$.

Ozturk, M., Ozozen, G., Minareci, O and Minareci, E. (2008). Determination of heavy metals in issues of fishes, water and sediment from the Demirkopru Dam Lake (Turkey). Journal of Applied Biological Sciences, 2(3): $99-104$.

Pattee, O.H and Pain, D.J. (2003). Lead in the environment. Pp. 373 - 408. In: Hoffman D.J., B.A Rattner, G.A. Burton Jr, J. Cairn Jr. (eds). Handbook of ecotoxicology, $2^{\text {nd }}$ edn. Lewis Publishers, Boca Raton, FL.

Pote, J., Haller, L., Loizeau, J.L Bravo, A.G., Satre, G. and Wildi, W. (2008). Effects of sewage treatment plant oulet pipe extension on the distribution of contaminants in the sediments of the Bay of Vidy, lake Geneva, Switzerland. Bioresource Technology, 99: 7122 - 7131.

Praveena, S.M., Radojevic, M., Abdullah, M.H and Aris, A.Z. (2008). Application of sediment quality guidelines in the assessment of mangrove surface sediment in Mengkabong lagoon, Sabah, Maleysia. Iran Journal of Environment, Health Science and Engineering, 5(1): $35-42$.
SON, (2007). Standards for drinking water quality.

www.unicef.org/nigeria/ng_publications Nige rian_Standard_for_Drinking_Water_Quality.p df. Retrieved June, 14, 2010.

Storelli, M.M., Storelli, A., D'ddaabbo, R., Morano, C., Bruno, $\mathrm{R}$ and Marcotrigiano, G.O. (2005). Trace Elements in loggerhead turtles (Caretta caretta) from the Eastern Mediterranean; Overview and Evaluation. Environmental Pollution, 135: 163 - 170.

UNEP, (1985). Reference methods for marine pollution studies, Determination of total $\mathrm{Hg}$ in marine Sediments and suspended solids by cold vapour AAS, 26.

Welz, B and Sperling, M.(1999). Atomic absorption Spectrophotometry, $3^{\text {rd }}$ edn, Wiley$\mathrm{VCH}$, Weinheim.

WHO (World Health Organisation), (2003). Malathion in drinking water. Background document for preparation of WHO guidelines for drinking water quality, Geneva, World Health Organistaion (WHO/SDE/WSH/03.04/103).

WPCL (Water Pollution Control Legislation), (2004). Land based water quality classification. Official Journal, 25687, Turkey. Wyse, E.J., Azemard, S and Mora, S.J. (2005). Report on the world wide inter-comparison exercise for the determination of trace elements and methyl mercury in fish Homogenate. IAEA-407, IAEA/AL/144 (IAEA/MEL/72), IAEA, Monaco.

\section{ACKNOWLEDGEMENT}

We acknowledge Mr. Adeola Bamgboye of Light House Petroleum Engineering Company Limited for the use of their laboratory facilities for biochemical analyses. 